\title{
Penerapan sosiodrama untuk meningkatkan kemampuan resolusi konflik pada komunitas anak jalanan kendari
}

\author{
Ishlah Hakim \\ Program Studi Bimbingan Konseling, Program Pascasarjana UNM \\ email :ishlah.hakim84@gmail.com
}

(Diterima: 25-April-2016; direvisi:03-Juni-2016; dipublikasikan: 28-Juni-2016)

\begin{abstract}
The research is amimed to know whether or not the application of sociodrama is abe to enhance conflict resolution skill towards the street children community in Kendari. This reserch was quantitaitve research using experimental approach. The experimental research design used is pre-experimental design in the form of one group pre-test-posterst design. The data collection used is scale, observation, and FGD (Focus Group Discussion). The population in the research is 42 people. The sample in the research consisted of 12 people. The sampling in the research used is nonprobskill sampling with sampling purposive technique. The data of the research was analyzed quantitatively using Wilcoxon signed ranks test. The findings shows that sociodrama was able to enhance the conflict resolution skill towards the street children community in Kendari.
\end{abstract}

Keywords: Sociodrama; Conflict resolution skill.

\begin{abstract}
Abstrak:Penelitian bertujuan untuk mengetahui apakah penerapan sosiodrama mampu meningkatkan kemampuan resolusi konflik pada Komunitas Anak Jalanan Kendari di Kota Kendari. Penelitian ini merupakan penelitian kuantitatif dengan menggunakan pendekatan eksperimen. Desain eksperimen yang digunakan di dalam penelitian ini adalah pre-experimental design dalam bentuk one group pretest-posttest design.Pengumpulan data penelitian menggunakan skala, observasi, dan FGD (Focuss Group Discussion). Populasi dalam penelitian ini berjumlah 42 orang. Adapun sampel di dalam penelitian ini berjumlah 12 orang. Penarikan sampel dalam penelitian ini menggunakan nonprobability sampling dengan teknik sampling purposive. Data di dalam penelitian ini dianalisis secara kuantitatif melalui Wilcoxon signed ranks test. Hasil penelitian menunjukkan bahwa sosiodrama mampu meningkatkan kemampuan resolusi konflik pada Komunitas Anak Jalanan Kota Kendari.
\end{abstract}

Kata Kunci: Sosiodrama;kemampuan resolusi konflik.

Copyright (C) 2016 Universitas Negeri Makassar. This is an open access article under the CC BYNC-ND license (http://creativecommons.org/licenses/by-nc-nd/4.0/).

\section{PENDAHULUAN}

Menurut Undang-Undang Nomor 23 Tahun 2002 Pasal 1 bahwa "Anak adalah seseorang yang belum berusia 18 (delapan belas) tahun, termasuk anak yang masih dalam kandungan". Anak merupakan individu yang tumbuh dan berkembang dan diharapkan mampu menjadi tonggak penerus kemajuan suatu bangsa. Oleh karena itu setiap anak harus memperoleh pendidikan yang layak. Hal ini merupakan amanah Undang-Undang Nomor 23 Tahun 2002 Pasal 9 Ayat (1) yang berbunyi "Setiap anak berhak memperoleh pendidikan dan pengajaran dalam rangka pengembangan pribadinya dan 
tingkat kecerdasannya sesuai dengan minat dan bakatnya".

Pada saat ini amanah yang dititipkan oleh undang-undang yang disebutkan di atas nampaknya tidak terlaksana secara optimal. Dalam kehidupan sehari-hari sering ditemukan anak usia sekolah yang tidak bersekolah dan memilih untuk hidup di jalanan sebagai anak jalanan. Kondisi seperti ini seharusnya tidak terjadi dalam kehidupan anak karena bertentangan dengan undang-undang dan tidak sesuai dengan kodrat kehidupan yang seharusnya dijalani oleh seorang anak yang sedang tumbuh dan berkembang serta membutuhkan perhatian khusus.

Kota Kendari merupakan salah satu wilayah yang mulai berkembang. Dalam kasus anak jalanan, Kota Kendari juga tidak luput dari masalah tersebut. Anak-anak jalanan dengan mudah dijumpai di tempat-tempat umum dan pusat keramaian seperti pasar, terminal, pusat pertokoan, traffict light, pelabuhan, pelelangan, dan sebagainya. Kehidupan anak jalanan terutama berhubungan dengan ekonomi, antara lain mengamen, mengemis, pedagang asongan, kuli, loper koran, pembersih kendaraan, dan sebagainya. Mereka mendapatkan upah seadanya, bahkan ada beberapa anak yang bekerja tanpa diberikan upah.

Sebagian besar di Kota Kendari menjadi anak jalanan dengan alasan membantu keluarga memenuhi kebutuhan hidup. Sehingga anak-anak yang bekerja di jalan berupaya bekerja keras dalam meningkatkan taraf hidup. Tidak jarang pula mereka dicap sebagai pembuat onar, pengganggu ketertiban dan membuat Kota menjadi kotor. Di berbagai sudut Kota anak jalanan harus bertahan hidup dengan cara-cara yang secara sosial kurang atau bahkan tidak dapat diterima masyarakat umum, sekedar untuk menghilangkan rasa lapar dan keterpaksaan untuk membantu keluarganya.

Anak-anak yang hidup dan tinggal di jalanan memicu penurunan kualitas intelektual dan daya saing individu pada masa yang akan datang.Kurangnya pendidikan yang didapatkan akan menyebabkan adanya ketidakpahaman tentang norma-norma kehidupan sehingga berpotensi menimbulkan berbagai masalah dalam kehidupan sosial. Hal ini diperparah lagi dengan kondisi yang menempatkan pemenuhan kebutuhan sebagai prioritas utama anak untuk bekerja. Setiap anak yang bekerja di jalan berkompetisi memperoleh hasil kerja yang sebanyak-banyaknya. Mengharap untuk mendapat hasil yang lebih banyak dari anak yang lain sehingga tidak jarang menimbulkan konflik di antara sesama anak jalanan.

Konflik-konflik yang sering timbul pada anak jalanan di Kota Kendari antara lain anak menjadi resah, kecemasan, malas ke sekolah karena keasyikan mencari uang, merasa dipaksa oleh orang-orang terdekat untuk mencari uang demi memenuhi kebutuhan hidup, anak jalanan yang lebih besar sering menindas anak yang lebih kecil, sampai pada kasus perkelahian sesama anak jalanan. Bahkan yang terparah adalah anak-anak pada kategori ini rawan terhadap perlakuan salah, baik secara sosial, emosional, fisik, maupun seksual (Irwanto dkk, dalam Suyanto, 2013: 201).

Permasalahan anak jalanan ini disikapi oleh pemerintah Kota Kendari dengan membentuk Komunitas Anak Jalanan Kendari (KOJAK) di bawah naungan Yayasan Pengembangan Sumber Daya Manusia (SDM) Tripilar Lambelu. Komunitas ini di dirikan di Kota Kendari pada tanggal 21 Februari 2008. Komunitas ini merupakan wadah perkumpulan anak jalanan yang bertugas membina anak jalanan dengan memberikan pendidikan untuk membantu pengembangan potensi diri anak jalanan utamanya bagi yang berada pada usia sekolah. KOJAK merupakan salah satu wadah bagi anakanak jalanan di seputaran Kecamatan Mandonga Kota Kendari. Melihat kondisi masih banyak anak jalanan yang belum bisa baca, tulis, dan hitung menjadi alasan KOJAK memberikan bimbingan buat anak jalanan agar mereka bisa terbebas dari ancaman buta aksara. Selain itu, KOJAK juga memberikan pembelajaran kerohanian melalui belajar shalat, mengaji, maupun bercerita tentang kisah nabi dan para sahabat, dan kisah-kisah teladan. Karena itulah misi utama komunitas ini adalah memberikan pendidikan kepada anak jalanan.

Berdasarkan informasi yang didapatkan dari pengajar dan relawan KOJAK pada bulan April 2014, diperoleh data bahwa anak jalanan yang tergabung dalam komunitas ini rentan mengalami konflik yang berasal dari diri mereka, seperti kecemasan, malas sekolah, minder, maupun dari luar, utamanya dari orang terdekat mereka. Hal ini disebabkan oleh ketidakmampuan anak jalanan dalam menyelesaikan masalah yang terjadi di antara mereka dengan tangan dingin. 
Masalah yang terjadi senantiasa diselesaikan dengan cara kekerasan sehingga berujung pada perkelahian. Beberapa anak mencoba menangani langsung konflik yang mereka hadapi, tetapi ada juga yang menggunakan bantuan orang lain (mediator), tetapi hasilnya tidak memuaskan. Selain itu, dilakukan pula observasi awal pada bulan januari 2015 untuk melihat secara langsung kondisi anak jalanan yang tergabung dalam KOJAK. Hasil observasi membuktikan bahwa sebagian besar anak jalanan yang tergabung dalam KOJAK kurang mampu menyelesaikan konflik. Perkelahian dan saling menghina merupakan cara yang paling dominan dilakukan untuk menyelesaikan konflik.

Informasi yang diuraikan di atas menggambarkan bahwa anak jalanan yang tergabung dalam KOJAK kurang mampu mengatasi konflik yang terjadi. Untuk itu, diperlukan upaya-upaya dalam meningkatkan kemampuan resolusi konflik pada anak jalanan yang tergabung dalam KOJAK agar mampu untuk mengelola konflik yang terjadi sehingga mereka mampu mendapatkan zona nyaman dan iklim yang kondusif sesama anak jalanan. Baedowi (2011) mengemukakan bahwa pendidikan resolusi konflik dapat diimplementasikan melalui berbagai macam alternatif pendekatan yaitu: 1) melalui integrasi pendidikan resolusi konflik dalam setiap kurikulum mata pelajaran; 2) melalui layanan bimbingan konseling; 3) integrasi pendidikan resolusi konflik dalam setiap kebijakan, peraturan, visi, dan misi sekolah; dan 4) dapat dilaksanakan saat terjadi permasalahan, seperti pertengkaran dan perkelahian yang melibatkan antarkelompok.

Berdasarkan pendapat Baedowi (2011) di atas, penerapan pendidikan resolusi konflik dapat diterapkan melalui layanan bimbingan dan konseling (yang selanjutnya dalam penulisan ini disingkat BK). BK tidak lagi diterapkan pada lingkungan sekolah saja namun BK telah mampu masuk ke dalam lingkungan yang lebih luas lagi. Bila dicermati secara mendalam, permasalahan yang dihadapi oleh anak jalanan yang tergabung dalam KOJAK adalah ketidakmampuan dalam melakukan resolusi konflik. Salah satu upaya yang dapat dilakukan untuk memberikan pelajaran kepada anak jalanan mengenai resolusi konflik adalah melalui teknik sosiodrama yang dilakukan dalam setting konseling kelompok. Sosiodrama atau simulasi merupakan salah satu teknik yang cocok diterapkan dalam memberikan bantuan pada anak jalanan untuk mereduksi konflik yang terjadi pada diri atau kelompok, sekaligus juga mengajarkan tentang bagaimana mengaktualisasikan diri dalam kehidupan. Sosiodrama merupakan suatu cara membantu memecahkan masalah anak melalui drama. Pemecahan masalah individu diperoleh melalui penghayatan peran tentang situasi masalah yang dihadapinya (Tohirin, 2013: 276).

Sosiodrama akan membantu anak jalanan untuk menghadapi secara langsung konflik yang terjadi melalui pementasan drama. Melalui pementasan ini, anak jalanan akan mempelajari situasi dan kondisi yang terjadi pada saat konflik terjadi sehingga memungkinkan anak jalanan untuk mencari sendiri jalan keluar atas konflik yang dialami. Mengingat hal ini bersifat menarik untuk diteliti, maka penulis tertarik untuk melakukan penelitian dengan judul "pengaruh sosiodrama terhadap kemampuan resolusi konflik anak pada Komunitas Anak Jalanan Kendari di Kota Kendari".

Berdasarkan uraian sebelumnya, maka tujuan penelitian ini adalah untuk mengetahui apakah penerapan sosiodrama mampu meningkatkan kemampuan resolusi konflik pada Komunitas Anak Jalanan Kendari di Kota Kendari.

\section{METODE}

Penelitian ini merupakan penelitian kuantitatif dengan menggunakan pendekatan eksperimen.Desain eksperimen yang digunakan di dalam penelitian ini adalah pre-experimental design dalam bentuk one group pretest-posttest design. Populasi dalam penelitian ini adalah seluruh anak jalanan yang tergabung dalam KOJAK yang berjumlah 42 orang.Penarikan sampel dalam penelitian ini menggunakan nonprobability sampling dengan teknik purposive sampling. Sampel penelitian ini berjumlah 12 anak. Data dikumpulkan melalui skala, observasi, dan Focuss Group Discussion (FGD).

\section{HASIL DAN PEMBAHASAN}

Gambaran pelaksanaan sosiodrama. Pelaksanaan sosiodrama dilakukan sebanyak delapan kali pertemuan dengan rincian satu kali pretest, satu kali pertemuan untuk pengenalan 
sosiodrama kepada subjek penelitian, empat kali pertemuan dalam rangka pelaksanaan sosiodrama kepada subjek penelitian, satu kali pertemuan untuk Focuss Group Discussion, dan satu kali pertemuan untuk pelaksanaan posttest.

Pelaksanaan sosiodrama dalam membantu meningkatkan resolusi konflik anak pada Komunitas Anak Jalanan Kendari (KOJAK) di Kota Kendari diawali dengan tahap persiapan. Dalam tahap ini dilakukan persiapan sebelum perlakuan sosiodrama di lapangan, seperti membuat skenario yang akan ditampilkan, menetapkan jadwal pelaksanaan kegiatan, menata setting pelaksanaan sosiodrama, serta menyiapkan lembar observasi. Setelah tahap persiapan, tahap berikutnya adalah pelaksanaan kegiatan yang terdiri dari tiga sesi, yaitu 1) sesi awal pelaksanaan pretest (pertemuan pertama) dan pemberian informasi (pertemuan kedua), 2) sesi kegiatan: pelaksanaan sosiodrama: pelaksanaan sosiodrama tahap pertama "Kepuasan Diri" (pertemuan ketiga), pelaksanaan sosiodrama tahap kedua "Kita Sama Tapi Kita Beda" (pertemuan keempat), Pemberian sosiodrama tahap ketiga"Bangga Bersama Keluarga"(pertemuan kelima), dan Pemberian sosiodrama tahap keempat "Hidup Rukun Bersama Kalian" (pertemuan keenam) dan 3) Sesi akhir pasca pelaksanaan sosiodrama, terdiri dari Pelaksanaan Focuss Group Discussion (Pertemuan ketujuh) dan Pelaksanaan posttest (pertemuan kedelapan).

Gambaran tingkat kemampuan resolusi konflik anak jalanan sebelum dan setelah penerapan sosiodrama. Berdasarkan hasil pretest ditemukan bahwa tingkat kemampuan resolusi anak jalanan pada komunitas anak jalanan kota Kendari sebelum diberi sosiodrama adalah terdapat 4 anak jalanan $(33,33 \%)$ berada pada kategori sangat rendah, 6 anak jalanan $(50 \%)$ berada pada kategori rendah, 2 anak jalanan $(16,67 \%)$ berada pada kategori sedang, dan tidak terdapat anak jalanan $(0 \%)$ yang berada pada kategori tinggi dan sangat tinggi.

Berdasarkan hasil posttest diketahui bahwa tidak terdapat anak jalanan $(0 \%)$ yang tingkat kemampuan resolusi konfliknya pada kategori sangat rendah dan rendah, 6 anak jalanan (50\%) tingkat kemampuan resolusi konfliknya pada kategori sedang, 4 anak jalanan $(33,33 \%)$ tingkat kemampuan resolusi konfliknya pada kategori tinggi dan 2 anak jalanan $(16,67 \%)$ yang tingkat kemampuan resolusi konfliknya pada kategori sangat tinggi. Hasil ini menginformasikan bahwa tingkat kemampuan resolusi konflik pada saat pretest dapat dikategorikan "rendah" sedangkan setelah diberikan perlakuan maka tingkat kemampuan resolusi konflikdapat dikategorikan "tinggi".

Pengujian hipotesis. Berdasarkan hasil analisis uji Wilcoxon dengan menggunakan SPSS 20,0 for windows diketahui bahwa terdapat perbedaan signifikan nilai rata-rata setelah perlakuan lebih tinggi dari pada sebelum diberikan perlakuan pada sampel penelitian. Selanjutnya, hal ini dipertegas dari nilai gain score pada kelompok eksperimen yaitu 28,9. Berdasarkan uji statistik diperoleh nilai $\mathrm{Z}$ sebesar $-3,066$ dengan nilai asyimp.sig $=0,002<0,05$, hal ini berarti bahwa hipotesis nihil (H0) yang berbunyi "penerapan sosiodrama tidak dapat meningkatkan kemampuan resolusi konflik pada Komunitas Anak Jalanan Kendari (KOJAK) di Kota Kendari" dinyatakan ditolak. Sehingga hipotesis kerja (H1) yang berbunyi "penerapan sosiodrama dapat meningkatkan kemampuan resolusi konflik pada Komunitas Anak Jalanan Kendari (KOJAK) di Kota Kendari" dinyatakan diterima. Dasar pengambilan keputusan ini adalah hasil uji beda yaitu nilai asyimp. Sig $=$ 0,002 lebih kecil dari pada taraf kesalahan yang ditetapkan yaitu sebesar 0,05 .

Berdasarkan hasil uji hipotesis yang dilakukan maka dapat disimpulkan bahwa penerapan sosiodrama mampu meningkatkan kemampuan resolusi konflik pada Komunitas Anak Jalanan Kendari (KOJAK) di Kota Kendari. Hal ini dibuktikan berdasarkan uji statistik yang dilakukan.

Konflik merupakan suatu situasi yang membuat individu kurang merasa nyaman. Untuk itu, individu membutuhkan strategi yang dapat digunakan dalam mengelola konflik agar tidak memberikan dampak yang buruk bagi pengembangan diri individu. Salah satu upaya yang mampu dikembangkan adalah melalui upaya meningkatkan kemampuan resolusi konflik melalui teknik sosiodrama. Diharapkan melalui teknik ini anak jalanan yang tergabung dalam Komunitas Anak Jalanan Kota Kendari (KOJAK) selaku subjek penelitian mampu meningkatkan kemampuan resolusi konfliknya.

Berdasarkan hasil studi pendahuluan ditemukan bahwa anak jalanan yang tergabung dalam KOJAK rentan mengalami konflik sesama anak jalanan. Hal ini disebabkan oleh 
ketidakmampuan anak jalanan dalam menyelesaikan masalah yang terjadi di antara mereka dengan tangan dingin. Masalah yang terjadi senantiasa diselesaikan dengan jalan kekerasan sehingga berujung pada perkelahian. Selain itu, hasil observasi membuktikan bahwa sebagian besar anak jalanan yang tergabung dalam KOJAK kurang mampu menghadapi permasalahan dengan kepala dingin. Perkelahian dan saling menghina merupakan cara yang paling dominan dilakukan untuk menyelesaikan masalah. Melalui kegiatan pretest diketahui bahwa tingkat kemampuan resolusi konflik subjek penelitian yang berjumlah 12 orang dikategorikan "rendah" sedangkan setelah diberikan perlakuan melalui teknik sosiodrama maka kemampuan resolusi konflik subjek penelitian menjadi "tinggi".

Hasil penelitian menunjukkan bahwa terjadi peningkatan yang signifikan terhadap tingkat kemampuan resolusi konflik anak jalanan setelah diberikan sosiodrama. Hal ini diperkuat oleh hasil uji statistik yang menyatakan bahwa pada tingkat signifikansi 0,05 , sosiodrama terbukti secara signifikan mampu meningkatkan kemampuan resolusi konflik anak jalanan. Hasil penelitian ini menguatkan bahwa sosiodrama mampu meningkatkan kemampuan resolusi konflik anak jalanan pada Komunitas Anak Jalanan Kota Kendari (KOJAK).

Sebagai sebuah teknik, sosiodrama merupakan suatu kegiatan menyenangkan yang mudah dilakukan oleh siapa saja. Hal ini diperkuat dengan pendapat dari Djumhur \& Surya (2001:109) bahwa "Sosiodrama dipergunakan sebagai suatu teknik di dalam memecahkan masalah-masalah sosial dengan melalui kegiatan bermain peran". Kegiatan ini dilakukan dengan maksud agar individu mampu belajar menginternalisasi nilai-nilai kehidupan yang tersirat dalam drama yang diperankan. Nilai-nilai yang diinternalisasi kemudian menjadi bahan perenungan bagi individu yang terlibat dalam pelaksanaan sosiodrama. Hasil dari bahan perenungan tersebut kemudian akan dinilai oleh peserta sosiodrama yang pada akhirnya akan dijadikan sebagai suatu nilai yang akan dipedomani di dalam kehidupan.

Implikasi lebih lanjut dari penelitian ini adalah guru Bimbingan dan Konseling (BK) agar di dalam pelaksanaan pelayanan BK di sekolah mampu menyertakan teknik sosiodrama dalam membantu anak dalam penyelesaian masalah yang menyangkut kehidupan sosial. Dengan sosiodrama maka anak akan mampu mempelajari miniatur kehidupan sosial dalam skala kecil sebelum anak menghadapi kehidupan sosial yang sesungguhnya. Pembelajaran yang dipetik melalui sosiodrama akan mengakibatkan anak mampu mengintrospeksi diri khususnya menyangkut segala bentuk perilaku anak dalam kehidupannya sehari-hari.

\section{SIMPULAN DAN SARAN}

Berdasarkan hasil penelitian dapat dikemukakan kesimpulan bahwa tingkat kemampuan resolusi konflik pada Komunitas Anak Jalanan Kota Kendari (KOJAK), berdasarkan hasil pretest berada pada kategori rendah. Namun demikian, setelah diberi sosiodrama menunjukkan perubahan dari tingkat kemampuan resolusi konflik rendah menjadi kategori tinggi, sehingga sosiodrama mampu meningkatkan kemampuan resolusi konflik pada Komunitas Anak Jalanan Kota Kendari (KOJAK).

Selanjutnya, diajukan saran-saran sebagai berikut: 1) Anak jalanan menjadi bagian tak terpisahkan dari Dinas Sosial. Upaya penerapan sosiodrama sebagai teknik dalam konseling kelompok membutuhkan sarana dan prasarana yang memadai, khususnya berkaitan dengan tempat pelaksanaan yang layak. Olehnya itu, Dinas Sosial hendaknya menyediakan tempat yang memadai untuk menunjang pelaksanaan teknik ini. 2) Dalam pelaksanaannya, sosiodrama dilakukan dalam situasi konseling baik itu secara individu maupun kelompok serta bimbingan kelompok. Untuk itu, diharapkan pengelola KOJAK agar kiranya mengajak insan-insan BK yang ada di kota Kendari untuk memberikan sumbangsih tenaganya sebagai relawan KOJAK. Hal ini dilakukan karena pelaksanaan sosiodrama hanya mampu dilakukan oleh individu-individu yang memahami dunia BK. 3) Bagi yang tertarik untuk melakukan penelitian lanjutan terhadap penelitian ini, peneliti perlu menggunakan desain penelitian yang lebih baik agar hasil penelitian memperoleh tingkat pengambilan keputusan yang relatif lebih valid. 


\section{DAFTAR RUJUKAN}

Baedowi, A. (2011). Resolusi Konflik di Sekolah (Online), (http://www.kickandy.com/friend/4/37/2 186/read/Resolusi-Konflik-di-

sekolah.html, Diakses pada tanggal 20 April 2015)

Djumhur \& Surya, M. (200)1. Bimbingan dan Penyuluhan di Sekolah. Bandung: CV. Ilmu.

KoJAK (Komunitas Anak Jalanan Kendari).2014.

http://www.sultranesia.com/2014/03/koj ak-komunitas-anak-jalanan-kendari.html

Suyanto, B. (2013). Masalah Sosial Anak. Jakarta: Kencana Prenada Media Group.

Tohirin. (20130. Bimbingan dan Konseling di Sekolah dan Madrasah (Berbasis Integrasi). Jakarta: PT. RajaGrafindo Persada.

Undang-Undang Republik Indonesia Nomor 23 Tahun 2002 Tentang Perlindungan Anak. 2012. Bandung: Citra Umbara. 